\title{
Hydrotalcites in Construction Materials
}

\author{
Anna-Marie Lauermannová ${ }^{1}{ }^{10}$, Iva Paterová ${ }^{2}$, Jan Patera $^{2}$, Kryštof Skrbek ${ }^{1}$, \\ Ondřej Jankovský ${ }^{1}$ (ID and Vilém Bartůněk ${ }^{1, *}$ \\ 1 Department of Inorganic Chemistry, Faculty of Chemical Technology, University of Chemistry \\ and Technology, Prague, Technická 5, 16628 Prague, Czech Republic; lauermaa@vscht.cz (A.-M.L.); \\ krystof.skrbek@vscht.cz (K.S.); ondrej.jankovsky@vscht.cz (O.J.) \\ 2 Department of Organic Technology, Faculty of Chemical Technology, University of Chemistry and \\ Technology, Prague, Technická 5, 16628 Prague, Czech Republic; iva.paterova@vscht.cz (I.P.); \\ jan.patera@vscht.cz (J.P.) \\ * Correspondence: vilem.bartunek@vscht.cz; Tel.: +42-022-0443-765
}

Received: 25 September 2020; Accepted: 9 November 2020; Published: 11 November 2020

Featured Application: In this contribution, the applications of the hydrotalcites and hydrotalcite-like materials in the building materials, cements, mortars, and concretes are summarized.

\begin{abstract}
Hydrotalcites are layered double hydroxides displaying a variety of stoichiometry caused by the different arrangement of the stacking of the layers, ordering of the metal cations, as well as the arrangement of anions and water molecules, in the interlayer galleries. The compounds of the hydrotalcite group show a wide range of the possible applications due to their specific properties, such as their large surface area, ion exchange ability, the insolubility in water and most of the organic sorbents, and others. Affordability, wide possibilities of manufacturing, and presence of sufficient natural deposits make hydrotalcites potentially very useful for the construction industry, as either a building material itself or an additive in mortars, concrete or in polymers composites used in constructions. Similar possible application of such material is in leakage control in a radioactive waste repository. The effect of use of these materials for ion exchange, anti-corrosion protection, radioactive ions containment, and similar purposes in building materials is examined in this review.
\end{abstract}

Keywords: hydrotalcite; layered double hydroxides; building materials; concrete; cement

\section{Introduction}

Hydrotalcites are layered minerals of both natural and synthetic origin, which are structurally derived from the brucite mineral- $\mathrm{Mg}(\mathrm{OH})_{2}$. Generally, they consist of three layers: two outer layers having a positive charge, and an inner intermediate layer which contains water molecules and replaceable anions (see Figure 1a). In brucite, the ions are octahedral, the central atoms are divalent magnesium cations, and the octahedral peaks fill the hydroxyl groups. Mineral hydrotalcite $\mathrm{Mg}_{6} \mathrm{Al}_{2}(\mathrm{OH})_{16} \mathrm{CO}_{3} \cdot 4 \mathrm{H}_{2} \mathrm{O}$ is the first discovered [1] and the best-known representative of layered double hydroxides (LDHs). The typical SEM microstructure is shown in Figure $1 \mathrm{~b}$.

The chemical composition of LDHs is not limited exclusively to $\mathrm{Mg}$ and $\mathrm{Al}$ atoms but can be described by the general formula, $\left(\mathrm{M}^{2+}{ }_{1-\times} \mathrm{M}^{3+} \times(\mathrm{OH})_{2}\right)^{x+}\left(\mathrm{A}^{\mathrm{n}-} \times / \mathrm{n} \mathrm{yH}_{2} \mathrm{O}\right)^{\times-}$, where some divalent cations $\mathrm{M}^{2+}$ are isomorphically replaced by trivalent $\mathrm{M}^{3+}$ cations. Originally, electroneutral hydroxide layers thus obtain a positive charge, which is compensated by the charge of anions $\mathrm{A}^{\mathrm{n}-}$ located in the interlayer together with the molecules of crystalline water. The value of $x$ in the above formula is equal to the molar ratio of trivalent cations in the hydroxide layers, $\mathrm{M}^{3+} /\left(\mathrm{M}^{2+}+\mathrm{M}^{3+}\right)$, and usually, lies in the range between 0.20 and 0.33 [2]. 


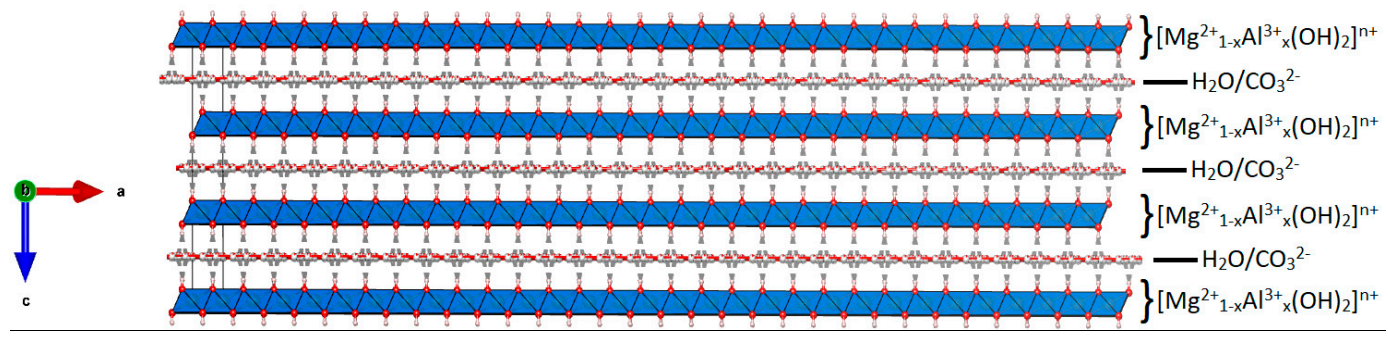

(a)

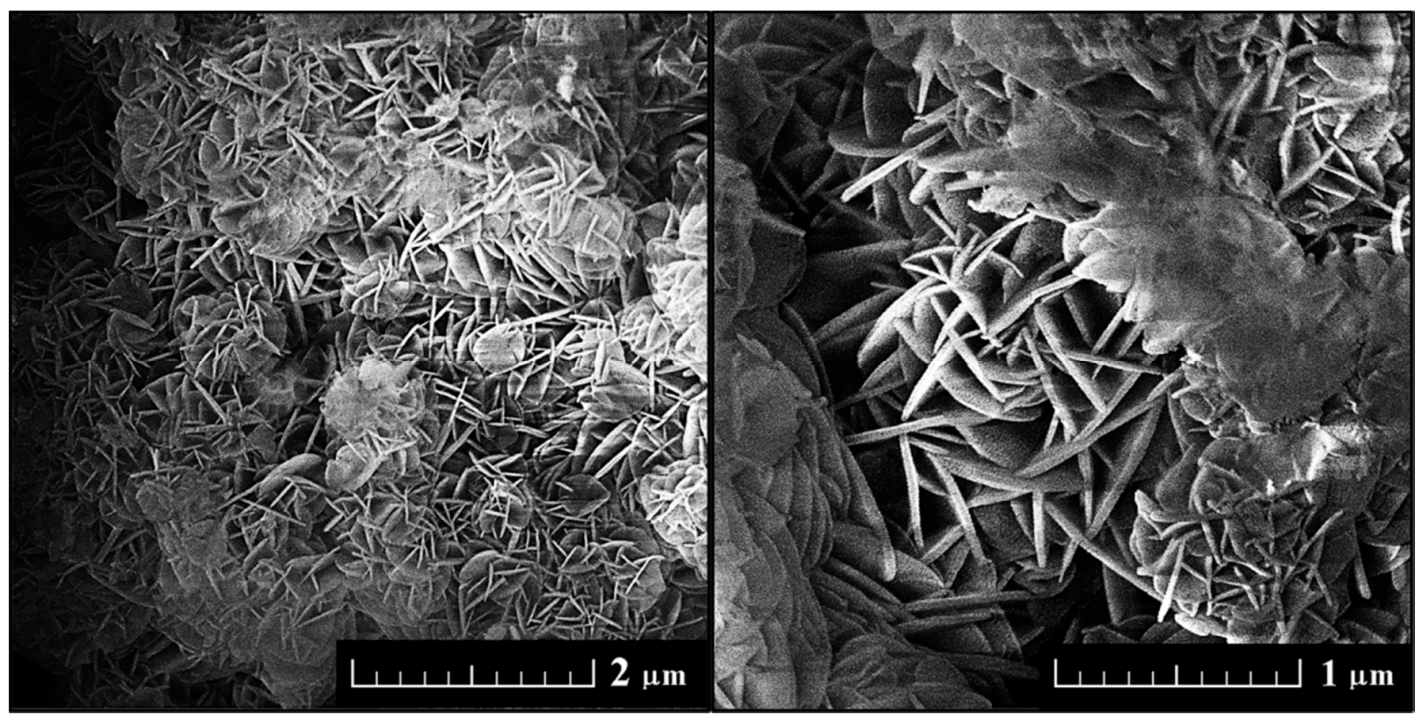

(b)

Figure 1. Typical structure of hydrotalcites (a) and SEM images of the hydrotalcyte sample with typical morphology (b).

Hydrotalcites have found the greatest practical use in the production and processing of polymers, especially as part of thermal stabilizing compounds for the processing of PVC, neutralizing additives, and flame retardants [3-5]. They find a very wide range of applications in heterogeneous catalysis, particularly as precursors for the synthesis of catalysts based on mixed oxides. They can be also used in sorption and decontamination processes or for the intercalation of various substances, including drugs. The most common minerals of the hydrotalcite group are listed in Table 1.

Table 1. Minerals of the hydrotalcite group.

\begin{tabular}{|c|c|c|c|}
\hline Type of Hydrotalcite & Cations & Space Group & Reference \\
\hline Hydrotalcite- $2 \mathrm{H}$ & $\mathrm{Mg}^{2+}, \mathrm{Al}^{3+}$ & $\mathrm{P}_{3} / \mathrm{mmc}$ & $\begin{array}{l}\text { Bookin, A.S. et al. [6], } \\
\text { Zhitova, E.S. et al. [7] }\end{array}$ \\
\hline Hydrotalcite-3R & $\mathrm{Mg}^{2+}, \mathrm{Al}^{3+}$ & $\mathrm{R} \overline{3} \mathrm{~m}$ & Mills, S. et al. [8], Zhitova, E.S. et al. [7] \\
\hline Desautelsite & $\mathrm{Mg}^{2+}, \mathrm{Mn}^{3+}$ & $\mathrm{R} \overline{3} \mathrm{~m}$ & Dunn, P.J. et al. [9] \\
\hline Droninoite & $\mathrm{Ni}^{2+}, \mathrm{Fe}^{2+}$ & $\mathrm{R} \overline{3} \mathrm{~m}$ & Chukanov, N.V. et al. [10] \\
\hline Iowaite & $\mathrm{Mg}^{2+}, \mathrm{Fe}^{2+}$ & $\mathrm{R} \overline{3} \mathrm{~m}$ & $\begin{array}{c}\text { Braithwaite, R.S.W. et al. [11] } \\
\text { Kohls, D.W. et al. [12] }\end{array}$ \\
\hline Meixnerite & $\mathrm{Mg}^{2+}, \mathrm{Al}^{3+}$ & $\mathrm{R} \overline{3} \mathrm{~m}$ & Mills, S. et al. [8], Koritnig, S. et al. [13] \\
\hline Pyroaurite- $2 \mathrm{H}$ & $\mathrm{Mg}^{2+}, \mathrm{Fe}^{3+}$ & $\mathrm{P}_{3} / \mathrm{mmc}$ & Ingram, L. et al. [14], Frondel, C. [15] \\
\hline Pyroaurite-3R & $\mathrm{Mg}^{2+}, \mathrm{Fe}^{3+}$ & $\mathrm{R} \overline{3} \mathrm{~m}$ & Ingram, L. et al. [14] \\
\hline Reevesite & $\mathrm{Ni}^{2+}, \mathrm{Fe}^{3+}$ & $\mathrm{R} \overline{3} \mathrm{~m}$ & Song, Y. et al. [16], Taylor, H. F. W. [17] \\
\hline Stichtite-2H & $\mathrm{Mg}^{2+}, \mathrm{Cr}^{3+}$ & $\mathrm{P}_{3} / \mathrm{mmc}$ & $\begin{array}{c}\text { Mills, S. et al. [18], } \\
\text { Ashwal, L.D. et al. [19] }\end{array}$ \\
\hline Stichtite-3R & $\mathrm{Mg}^{2+}, \mathrm{Cr}^{3+}$ & $\mathrm{R} \overline{3} \mathrm{~m}$ & $\begin{array}{c}\text { Mills, S. et al. [18], } \\
\text { Ashwal, L.D. et al. [19] }\end{array}$ \\
\hline Takovite & $\mathrm{Ni}^{2+}, \mathrm{Al}^{3+}$ & $\mathrm{R} \overline{3} \mathrm{~m}$ & $\begin{array}{l}\text { Bish, D. L. [20], Mills, S. et al. [8], } \\
\text { Maksimović, Z. [21] }\end{array}$ \\
\hline UM1998-10-CO:CoHNi & $\mathrm{Ni}^{2+}, \mathrm{Co}^{3+}$ & $\mathrm{R} \overline{3} \mathrm{~m}$ & Song, Y. et al. [16] \\
\hline UM2002-02-COH:FeNi & $\mathrm{Ni}^{2+}, \mathrm{Fe}^{3+}, \mathrm{Fe}^{2+}$ & $\mathrm{R} \overline{3} \mathrm{~m}$ & $\begin{array}{l}\text { Smith, D.G.W. et al. [22], } \\
\text { Maksimović, Z. et al. [23] }\end{array}$ \\
\hline Woodallite & $\mathrm{Mg}^{2+}, \mathrm{Cr}^{3+}$ & $\mathrm{R} \overline{3} \mathrm{~m}$ & Mills, S. et al. [24] \\
\hline Muskoxite & $\mathrm{Mg}^{2+}, \mathrm{Fe}^{3+}$ & $\mathrm{R} \overline{3} \mathrm{~m}$ & Jambor, J.L. [25] \\
\hline
\end{tabular}




\section{Synthesis of Hydrotalcites}

Hydrotalcite minerals with $\mathrm{Mg}^{2+}, \mathrm{Fe}^{2+}, \mathrm{Mn}^{2+}, \mathrm{Zn}^{2+}, \mathrm{Cu}^{2+}$, and $\mathrm{Ni}^{2+}$ anions in the position of $\mathrm{Mg}^{2+}$ ions are often found in natural geological deposits [26] and therefore can be obtained from such sources. However, sometimes it is necessary to synthesize hydrotalcite group materials to achieve sufficient purity or other desired properties.

The most used method of hydrotalcite synthesis is a coprecipitation of two metal salts in alkaline solution at aconstant $\mathrm{pH}$ value of approximately 10. A typical synthesis of a hydrotalcite employs a variation of a hydrothermal method, which often needs optimized reaction conditions to obtain desired product quality [27-31]. In addition, the hydrolysis reaction is often used [32, 33], as well as the sol-gel method [34,35]. The co-precipitation method is usually based on the simultaneous precipitation of inorganic salts from basic solutions at constant or at increasing $\mathrm{pH}$ [36]. The combustion method of synthesis can be advantageous because it involves a very rapid chemical process, the explosive decomposition of organic fuels, e.g., glycine or urea. Carbon dioxide and water formed during the combustion are employed in producing complexes with the metal ions [37,38]. Hydrotalcites obtained by the combustion process can be heated until the crystal lattice is destroyed, and subsequently recrystallized in a carbonate aqueous solution [39]. Sulphate-intercalated hydrotalcites for ammonia-nitrogen removal can be prepared using microwave-assisted synthesis. In this procedure the microwave irradiation contributes to the intercalation of sulphate anions to high crystallinity of the resulting material [40]. Another possibility is the preparation of hydrotalcites from industrial wastes. For example, the preparation of hydrotalcite from coal-combustion fly ash was explored. The synthesis was carried out as it is further described. Three molarity Three mol/L leaching solution of $\mathrm{HCl}, 30 \mathrm{~min}$ of aging at $65^{\circ} \mathrm{C}$ and $\mathrm{pH}$ of 11.5 , followed by crystallization for $12 \mathrm{~h}$ at $70{ }^{\circ} \mathrm{C}$. Prepared hydrotalcite has a large external surface area with low microporosity, and it consists of sub-micron plate-like particles. The structural features of hydrotalcite prepared from fly ash were comparable to the hydrotalcites synthesized from pure raw chemicals with the exception of the presence of calcite [41]. The hydrotalcite-like compounds were also prepared by calcination and subsequent pozzolanic reaction form paper sludge from the newsprint company, using only recycled paper as a raw material [42]. Similarly, the hydrotalcite-like compounds were synthesized by the hydration reaction of activated art paper sludge-lime mixtures at $20^{\circ} \mathrm{C}$ [43].

\section{General Application of the Hydrotalcites}

There are various possible applications of hydrotalcites. Due to the layered structure, hydrotalcites have a large surface area. They have great ion exchange ability and also, they are insoluble in water and most of the organic sorbents. Therefore, these materials, most commonly Mg-Al hydrotalcite, are suitable as basic heterogeneous catalysts for fine chemicals' synthesis. Due to their low reactivity, the as-prepared hydrotalcites must be activated before use as the catalysts. The first activation step consists of thermal decomposition of as-prepared Mg-Al hydrotalcite (see Figure 2).

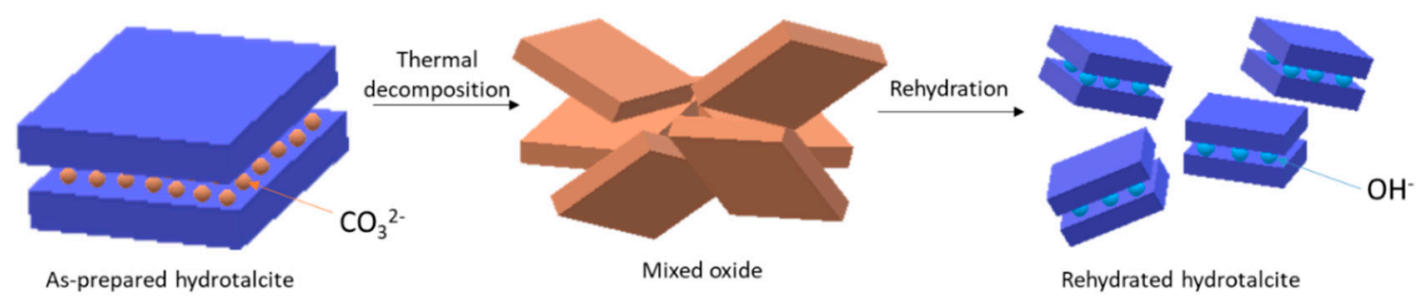

Figure 2. Hydrotalcite activation for catalysis.

Calcination of as-prepared $\mathrm{Mg}$-Al hydrotalcite below $550{ }^{\circ} \mathrm{C}$ results in the formation of a well-dispersed mixture of magnesium and aluminum oxides (mixed oxide, $\mathrm{MgAlO}$ ) with the presence of $\mathrm{Mg}^{2+}-\mathrm{O}^{2-}$ acid-base pairs (Lewis-type basicity). $\mathrm{Mg}$-Al mixed oxide has a so-called "memory effect", which allows the reconstruction of the original layered structure in contact with water. 
Therefore, the second activation step consists of rehydration of mixed oxide leading to hydrotalcite intercalated with $\mathrm{OH}^{-}$ion as compensating anions in the interlayer [44], which are Brønsted-type basic sites. These rehydrated hydrotalcites exhibit high activity in base-catalysed reactions which require Brønsted basicity, i.e., condensation reactions of aldehydes and ketones [45-51], Michael addition [52], Baeyer-Villiger oxidation [53,54], and others.

Hydrotalcites are also quite promising heterogeneous catalysts which enable the multistep processes, particularly when different and incompatible active sites are required [55]. Metal containing hydrotalcites are found to be very useful in many important industrial reactions, such as aldol condensation, followed by hydrogenation $[56,57]$.

The complex structure of hydrotalcites, enabling complexation of intercalated anions with various charged species, can be used in wastewater cleaning applications. For example, Mg-Al hydrotalcites can be used as adsorbents for the removal of chloride ions from wastewater [58]. In addition, Fe-Mg-Al hydrotalcites with different intercalated anions were evaluated as selective adsorbents for capturing heavy metals from a complex aqueous environment [59]. Adsorbents derived from hydrotalcites can be used for the removal of acute toxic drug diclofenac in wastewater [60], while the usual treatment processes are not able to totally eliminate this compound. Moreover, $\mathrm{Zn} / \mathrm{Al}$ layered double hydroxides can be used for the removal of nanoscale plastic debris from aqueous systems [61].

A medical application of hydrotalcite materials is also common, e.g., it can be used as an antacid. Usually, it is used together with aspirin without losing the medical effectiveness of both drugs [62]. Additionally, the hydrotalcites can be synthesized with bactericidal metal ions incorporated into the structure and used in cotton fibres for medical textile supplies [63]. Moreover, the hydrotalcites can be used as a raw material for various supplies, e.g., for black ceramic pigment [64].

Hydrotalcites also show very promising results in the ion-exchange technologies [65-68], where especially the anion exchange preference can be adjusted by different synthesis methods or anion occlusions [69]. The exchange properties are mainly affected by the interlayer anions [70].

Another very extensively studied problem, where the usage of hydrotalcites has great potential, is the $\mathrm{CO}_{2}$ and $\mathrm{H}_{2} \mathrm{O}$ capture [71,72]. In contrast to the materials which are widely used for the $\mathrm{CO}_{2}$ capture, such as zeolites or activated carbon, hydrotalcites show stable adsorption capacities at high temperatures $[73,74]$. This is a very important property used in the steam reforming processes [75], but also for the removal of carbon dioxide from power plant fuel gases and for the reduction of total carbon dioxide emissions [76,77].

\section{Hydrotalcites as a Part of the Building Materials}

Hydrotalcites as mineral substances, which are abundant and can be potentially easily produced on a large scale, came to consideration as a potential building material or appropriate additive in such materials. Because of their unique properties and low cost, they find usage especially as part of mortar and cement additives, where they prevent the chloride corrosion of concrete. Additionally, their sorption ability of dangerous material and usage in nuclear waste repositories, as well as application as a component of polymer composites, is very interesting, and it has been previously thoroughly studied [78-81]. The directions of application of hydrotalcites in the construction industry are described in the scheme (Figure 3).

\subsection{Application in Radioactive Waste Repository}

The ion exchange ability of the hydrotalcites may be utilized in special materials designed for containing ions of dangerous elements. Thermally treated hydrotalcites were examined for the sorption of the radioactive isotopes of iodine in the anion form. In the sample calcined at $773 \mathrm{~K}$ with the destroyed crystal lattice, increased sorption of I- anion was found, and hydrotalcite structure was reconstructed [82]. In addition, hydrotalcites are considered as possible material for anion scavengers for low-level radioactive waste repository backfills at near neutral $\mathrm{pH}$ for both $\mathrm{I}^{-}$and $\mathrm{TcO}_{4}{ }^{-}$anions [83]. 
Since hydrotalcites may be incorporated into various building material mixtures, mortars, concretes, and backfills, their application as accessible and affordable materials is prospective.

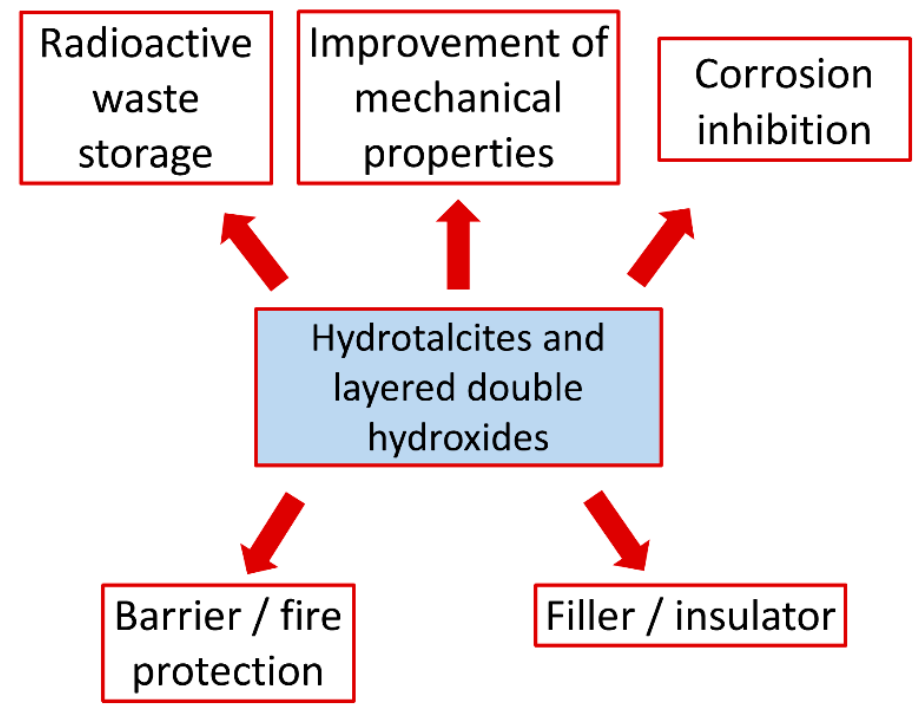

Figure 3. Scheme of application of hydrotalcites in building materials.

\subsection{Hydrotalcites in Reinforced Concrete as Corrosion Inhibitive Addition}

The main problem in reinforced concrete structures is the corrosion of the steel reinforcement, especially in coastal environments [84-86]. Usually, the reinforcement steel in solid concrete structure is passivated due to the high $\mathrm{pH}$ and therefore does not tend to corrode (see Figure 4) [87]. Nevertheless, in the presence of a sufficient level of chloride ions, the inner steel reinforcement can be de-passivated so the corrosion of the structure may start. This may occur especially after the exposition of the material to the seawater or in general, in the near-sea environment. The overall expenses of corrosion of reinforcement are considerable, as it involves repairing, restoration, and the safety monitoring activities, as well as aesthetics of concrete structures and components. Hence, it is vital to project concrete resistant to chloride corrosion.

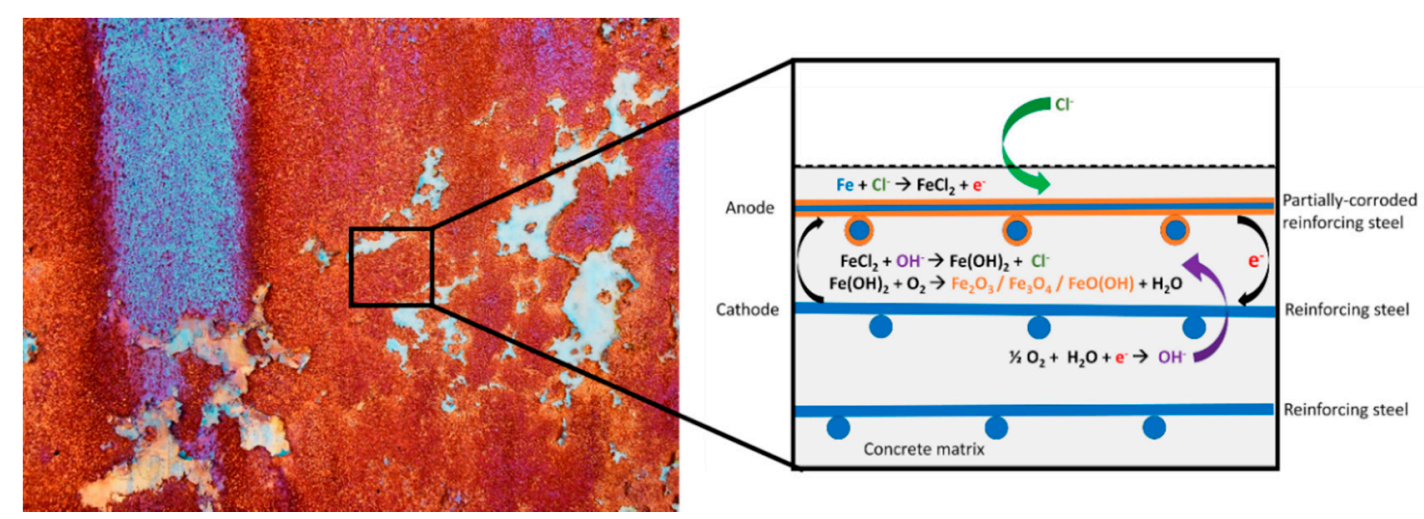

Figure 4. Scheme of the corrosion process.

In these days, there are several approaches of preventing the corrosion of concrete reinforcement. The first one is the use of surface coatings, which act as a barrier resistant to the chemical agents which can affect the concrete. The most common materials used for the coating are epoxy resin, polyurethane, acrylic coatings, polymer emulsion coatings, and chlorinated rubbers. The most important aspects which are being studied are their ability to adhere to the concrete, chloride permeability, the crack-brinding ability, and resistance to moisture and temperature variations. Previous studies showed high applicability 
of epoxy resin, which exhibits a good adhesion to concrete, as well as quite high effectiveness in reducing the water absorption causing the reduction of damage of the concrete reinforcement [88-90]. Another way of the anti-corrosion protection of concrete and concrete reinforcement is use of admixtures. The possible materials which can be used as an admixture are waste materials, such as coal fly ash or polymers, in the form of particles, short fibers, or organic liquids. Such materials not only work as an anti-corrosion agents but also improve the mechanical properties [91,92]. Another possible sort of material which can be used as an admixture are the hydrotalcites.

Hydrotalcites can be easily applied in some strategies of corrosion protection of concrete steel reinforcements $[93,94]$. The results of experiments showed that some configurations of Al-Mg hydrotalcites, with carbonate anions in the raw hydrotalcites substituted by different anions (e.g., p-aminobenzoate, pAB), displayed better corrosion inhibiting result in extended time before the beginning of the corrosion. It also showed a higher chloride threshold in comparison to the same free ions in solution. The mechanism is based on ion exchange between free chloride ions and the intercalated inhibitive anions in hydrotalcite matrix and simultaneous release inhibitive anions. These anions act as active inhibitors, causing the increase of a threshold concentration of chloride ions. The anionic exchange capacity of hydrotalcites is quite high (2-4.5 miliequivalents/g), making the exchange of interlayer ions easily achieved $[95,96]$. In addition, the influence of the addition of the anticorrosion material on mechanical properties is important. This statement was already previously mentioned in the literature [97,98]. The addition of $5 \%$ of pAB hydrotalcite in mortar specimens resulted in considerably improved resistance of the material to the chloride diffusion, accompanied with small decrease of compressive and flexural strength in units of MPa. Another promising way, besides the mentioned 5\% mass substitution of cement by $\mathrm{pAB}$ hydrotalcite in the bulk mortar, is the coating of reinforcing steel by part of cement paste coating $20 \% \mathrm{pAB} / \mathrm{NO}_{2}$ [99]. Additionally, relative $\mathrm{Mg}$-Al layered double hydroxides intercalated with hydroxide and organic anions can be applied as the corrosion inhibitors for carbon steel reinforced concrete [100]. However, the costs of hydrotalcite-like materials is quite high compared to the commonly used anti-corrosive materials.

\subsection{Hydrotalcites in Cements and Mortars}

An interesting application of hydrotalcites is in isolation of dangerous heavy metals in cement prepared from industrial waste. Hydrotalcites can be used for double barrier technique effect in cement-based mortars prepared for the immobilization of lead contained in electric arc furnace dust. Double barrier mortars with dimercaptosuccinate in the interlayer of the hydrotalcite reduced lead release by approximately $50 \%$ in comparison with the conventional immobilization mortar [101].

Hydrotalcites often form in mortars and cements, where supplementary cementitious materials are used as a substitute for cement clinker in order to reduce the emissions of cement production. This replacement was studied recently by using magnesium oxide [57], metakaolin [102], or dolomite [103]. The presence of alumina from a raw aluminosilicate may improve the mechanical behavior of resulting mortars. It may interact with hydrated magnesium oxide and form a hydrotalcite-like phase [58], while effectively improving the mechanical properties by an enhanced bond with the cementitious matrix [59]. In addition, a material containing hydrate water molecules can decrease the materials' overall porosity [60].

Hydration kinetics can be also modified using hydrotalcites, since it is believed, that the addition of nanoparticles lowers the energy barrier of liquid-state precipitation reactions. Hydrotalcites also provide additional nucleation sites, which are essential for the cement hydration reactions $[104,105]$.

The presence of hydrotalcites in concrete often affects the values of the compressive strength [106]. Many research studies show an increase of compressive strength, varying from units of percents to tens of percents $[107,108]$. Zou et al. referred to a $46,2 \%$ increase in compressive strength, which was attained by the addition of $1 \%$ LiAl layered double hydroxide [109]. However, it has been also reported that the presence of hydrotalcites leads to opposite effects [101]. Yang et al. used a 10\% addition of a $\mathrm{MgAl} \mathrm{NO} 2$ layered double hydroxide, which led to the decrease of compressive strength by $14,2 \%$ and 
the flexural strength by 19,1\% [110]. Xiong et al. observed a $25 \%$ compressive strength decrease after the addition of $1-3 \%$ of MgAl layered double hydroxide [111]. The differences between the positive and negative influence on the compressive strength depend on the microstructure of both the hydrotalcites used and the concrete. The usage of inappropriate hydrotalcites may cause the increase of porosity, which can also lead to faster ingress of chlorides or other undesired substances [111]. This porosity is also growing with the amount of hydrotalcites added to the concrete [112]. Additionally, the presence of hydrotalcites can lead to an increase in the compressive strength [106].

Hydrotalcites were also studied as additives in slag cements, where their presence allows to control kinetics and formation of the C-A-S-H phase [113] and also helps binding chlorides [114]. Another approach to hydrotalcites in cementitious materials was shown in the study of Raki et al., where the hydrotalcites were used as hosts for intercalation of organic admixtures in nanocomposites [115].

Hydrotalcites are also present in non-cement binders, such as in ground granulated blast furnace slags, where they are beside the C-S-H and $\mathrm{Ca}(\mathrm{OH})_{2}$ phase part of the reaction products, which define the strength of the material [116].

\subsection{Hydrotalcites in Polymer Composites}

Polyurethane foam is one of the most important thermosets widely used as an insulating material in the building and construction industry. Previously, it was shown that rigid foam composites with polyether polyol, isocyanate, a fire-retarding agent, hydrotalcite, and a PET can be formed [117]. It was shown that a small amount of hydrotalcite increases the compressive stress, but excessive hydrotalcite adversely affects the compressive stress. Additionally, flexible polyurethane foam nanocomposites with modified layered double hydroxides were studied [118]. In another paper, the effect of the addition of a phosphorus-containing polyol (E560) and hydrotalcites or another layered double hydroxides (LDH) to flexible polyurethane foams synthesized with a castor oil based polyol (LB50) was reported [119]. Interesting flame-retardant properties were observed for composites formed from hydrotalcites and tris (1-chloro-2-propyl) phosphate and isocyanate-based polyimide foams [120]. Preparation of hydrotalcites and isostructural layered double hydroxides and also their applications as additives in polymers was also described in detail. The use of hydrotalcites as heat retention additives in horticultural plastic films and as flame retardants was described. Hydrotalcites and other LDH can be also used as stabilizing agents for PVC or other polymers and for the stabilization of pigments in polymers [121].

\section{Conclusions}

The possible applications of the group of double-layered mineral hydroxides, called hydrotalcites, in building materials was reviewed. Hydrotalcites are suitable for various applications in building materials, such as mortars, cements, and polymer-composite materials due to their unique properties, namely ion exchange ability, large surface area, the insolubility in water, and, last but not least, their availability. Ion exchange properties can be utilized in anticorrosion protection of steel in reinforced concrete structures and for the storage of dangerous leakages from various waste dumps, including radioactive waste repository. Its mineral nature enables their utilization as flame retardants in polymer composites. Low price and high-availability allow its application as a quality cement clinker, which may result in reducing the emissions of cement production.

Author Contributions: Conceptualization, O.J., and V.B.; writing—original draft A.-M.L., K.S., O.J., V.B., I.P., and J.P. All authors have read and agreed to the published version of the manuscript.

Funding: This research was funded by the Czech Science Foundation, grant number 20-01866S.

Conflicts of Interest: The authors declare no conflict of interest. 


\section{References}

1. Manasse, E. Atti soc Toscana sc Nat. Proc. Verb. 1915, 24, 92.

2. Jakubikova, B.; Kovanda, F. Utilization of layered double hydroxides in medical applications. Chem. Listy 2010, 104, 906-912.

3. Gupta, S.; Agarwal, D.D.; Banerjee, S. Thermal stabilization of poly(vinyl chloride) by hydrotalcites, zeolites, and conventional stabilizers. J. Vinyl Addit. Technol. 2009, 15, 164-170. [CrossRef]

4. Gupta, S.; Agarwal, D.D.; Banerjee, S. Role of hydrotalcites cations in thermal stabilization of poly (vinyl chloride). Int. J. Polym. Mater. 2012, 61, 124-135. [CrossRef]

5. Hitt, D.J.; Haworth, B.; Thomas, N.L.; Algahtani, M.A. Melt compounding of rigid pvc formulations with hydrotalcites. Plast. Rubber Compos. 2008, 37, 445-452. [CrossRef]

6. Bookin, A.S.; Drits, V.A. Polytype diversity of the hydrotalcite-like minerals i. Possible polytypes and their diffraction features. Clays Clay Miner. 1993, 41, 551-557. [CrossRef]

7. Zhitova, E.; Yakovenchuk, V.; Krivovichev, S.; Zolotarev, A.; Pakhomovsky, Y.A.; Ivanyuk, G.Y. Crystal chemistry of natural layered double hydroxides. 3 . The crystal structure of $\mathrm{mg}$, al-disordered quintinite-2h. Miner. Mag. 2010, 74, 841-848. [CrossRef]

8. Mills, S.J.; Christy, A.G.; Génin, J.M.R.; Kameda, T.; Colombo, F. Nomenclature of the hydrotalcite supergroup: Natural layered double hydroxides. Miner. Mag. 2012, 76, 1289-1336. [CrossRef]

9. Dunn, P.J.; Peacor, D.R.; Palmer, T.D. Desautelsite, a new mineral of the pyroaurite group. Am. Miner. 1979, 64, 127-130.

10. Chukanov, N.V.; Pekov, I.V.; Levitskaya, L.A.; Zadov, A.E. Droninoite, $\mathrm{Ni}_{3} \mathrm{Fe}_{3}+\mathrm{Cl}(\mathrm{OH}) 8$ 2H2O, a new hydrotalcite-group mineral species from the weathered dronino meteorite. Geol. Ore Deposits 2009, 51, 767-773. [CrossRef]

11. Braithwaite, R.S.W.; Dunn, P.J.; Pritchard, R.G.; Paar, W.H. Iowaite, a re-investigation. Miner. Magaz. 1994, 58, 79-85. [CrossRef]

12. Kohls, D.W.; Rodda, J.L. Iowaite, a new hydrous magnesium hydroxide-ferric oxychloride from the precambrian of iowa. Am. Miner. 1967, 52, 1261-1271.

13. Koritnig, S.; Süsse, P. Meixnerit, mg6al2(oh)18-4h2o, ein neues magnesium-aluminium-hydroxid-mineral. Tsch. Miner. Petrograph. Mitt. 1975, 22, 79-87. [CrossRef]

14. Ingram, L.; Taylor, H.F.W. The crystal structures of sjögrenite and pyroaurite. Miner. Magaz. J. Miner. Soc. 1967, 36, 465-479. [CrossRef]

15. Frondel, C. Constitution and polymorphism of the pyroaurite and sjogrenite groups. Am. Miner. 1941, 26, 295-315.

16. Song, Y.; Moon, H.S. Additional data on reevesite and its co-analogue, as a new member of the hydrotalcite group. Clay Miner. 1998, 33, 285-296. [CrossRef]

17. Taylor, H. Crystal structures of some double hydroxide minerals. Miner. Magaz. 1973, 39, 377-389. [CrossRef]

18. Mills, S.; Whitfield, P.; Wilson, S.; Woodhouse, J.N.; Dipple, G.; Raudsepp, M.; Francis, C. The crystal structure of stichtite, re-examination of barbertonite, and the nature of polytypism in mgcr hydrotalcites. Am. Miner. 2011, 96, 179-187. [CrossRef]

19. Ashwal, L.D.; Cairncross, B. Mineralogy and origin of stichtite in chromite-bearing serpentinites. Contrib. Miner. Petrol. 1997, 127, 75-86. [CrossRef]

20. Bish, D.L.; Brindley, G.W. A reinvestigation of takovite, a nickel aluminum hydroxy-carbonate of the pyroaurite group. Am. Miner. 1977, 62, 458-464.

21. Maksimović, Z. Takovite, hydrous nickel aluminate, a new mineral. Zapisnici Srpskog Geoloskog Drustva. Compte Rendu Séances Soc. Serb. Géol. 1957, 1955, 219-224.

22. Smith, D.G.W.; Nickel, E.H. A system of codification for unnamed minerals: Report of the subcommittee for unnamed minerals of the ima commission on new minerals, nomenclature and classification. Can. Miner. 2007, 45, 983-990. [CrossRef]

23. Maksimović, Z.; Pantó, G.; Nagy, G. Iron-rich reevesitefrom the ni-fe ores of mt. Radočelo, serbia, a possible new member of the hydrotalcite subgroup. Acta Geol. Hung. 2002, 45, 373-383. [CrossRef]

24. Mills, S.; Whitfield, P.; Kampf, A.; Wilson, S.; Dipple, G.; Raudsepp, M.; Favreau, G. Contribution to the crystallography of hydrotalcites: The crystal structures of woodallite and takovite. J. Geosci. 2012, 57. [CrossRef] 
25. Jambor, J.L. Muskoxite, a new hydrous magnesium-ferric iron oxide from the muskox intrusion, northwest territories, canada. Am. Miner. 1969, 54, 684-696.

26. Lozano, R.P.; Rossi, C.; La Iglesia, A.; Matesanz, E. Zaccagnaite-3r, a new zn-al hydrotalcite polytype from el soplao cave (cantabria, spain). Am. Miner. 2012, 97, 513-523. [CrossRef]

27. Jing, F.L.; Zhang, Y.Y.; Luo, S.Z.; Chu, W.; Qian, W.Z. Nano-size mznal ( $\mathrm{m}=\mathrm{cu}$, co, ni) metal oxides obtained by combining hydrothermal synthesis with urea homogeneous precipitation procedures. Appl. Clay Sci. 2010, 48, 203-207. [CrossRef]

28. Kloprogge, J.T.; Hickey, L.; Frost, R.L. The effects of synthesis ph and hydrothermal treatment on the formation of zinc aluminum hydrotalcites. J. Solid State Chem. 2004, 177, 4047-4057. [CrossRef]

29. Othman, M.R.; Helwani, Z.; Martunus; Fernando, W.J.N. Synthetic hydrotalcites from different routes and their application as catalysts and gas adsorbents: A review. Appl. Organomet. Chem. 2009, 23, 335-346. [CrossRef]

30. Pan, G.X.; Xia, X.H.; Luo, J.S.; Cao, F.; Yang, Z.H.; Fan, H.J. Preparation of coal layered double hydroxide nanoflake arrays and their high supercapacitance performance. Appl. Clay Sci. 2014, 102, 28-32.

31. Yang, Z.Y.; Zhou, H.W.; Zhang, J.C.; Cao, W.L. Relationship between al/mg ratio and the stability of single-layer hydrotalcite. Acta Phys. Chim. Sin. 2007, 23, 795-800. [CrossRef]

32. Cavani, F.; Trifiro, F.; Vaccari, A. Hydrotalcite-type anionic clays: Preparation, properties and applications. Catal. Today 1991, 11, 173-301. [CrossRef]

33. Rao, M.M.; Reddy, B.R.; Jayalakshmi, M.; Jaya, V.S.; Sridhar, B. Hydrothermal synthesis of mg-al hydrotalcites by urea hydrolysis. Mater. Res. Bull. 2005, 40, 347-359. [CrossRef]

34. Aramendia, M.A.; Borau, V.; Jimenez, U.; Marinas, J.M.; Ruiz, J.R.; Urbano, F.J. Comparative study of $\mathrm{mg} / \mathrm{m}$ (iii) ( $\mathrm{m}=\mathrm{al}$, ga, in) layered double hydroxides obtained by coprecipitation and the sol-gel method. J. Solid State Chem. 2002, 168, 156-161. [CrossRef]

35. Prinetto, F.; Ghiotti, G.; Graffin, P.; Tichit, D. Synthesis and characterization of sol-gel mg/al and ni/al layered double hydroxides and comparison with co-precipitated samples. Microporous Mesoporous Mater. 2000, 39, 229-247. [CrossRef]

36. Zhang, W.H.; Guo, X.D.; He, J.; Qian, Z.Y. Preparation of ni(ii)/ti(iv) layered double hydroxide at high supersaturation. J. Eur. Ceram. Soc. 2008, 28, 1623-1629. [CrossRef]

37. Patil, K.C.; Aruna, S.T.; Mimani, T. Combustion synthesis: An update. Curr. Opin. Solid State Mater. Sci. 2002, 6, 507-512. [CrossRef]

38. Patil, K.C.; Aruna, S.T.; Ekambaram, S. Combustion synthesis. Curr. Opin. Solid State Mater. Sci. 1997, 2, 158-165. [CrossRef]

39. Davila, V.; Lima, E.; Bulbulian, S.; Bosch, P. Mixed mg(al)o oxides synthesized by the combustion method and their recrystallization to hydrotalcites. Microporous Mesoporous Mater. 2008, 107, 240-246. [CrossRef]

40. Chen, C.R.; Zeng, H.Y.; Xu, S.; Liu, X.J.; Xiao, H.M.; Duan, H.Z. Microwave-assisted preparation of so42intercalated hydrotalcites for ammonia-nitrogen removal. RSC Adv. 2016, 6, 12753-12760. [CrossRef]

41. Muriithi, G.N.; Petrik, L.F.; Gitari, W.M.; Doucet, F.J. Synthesis and characterization of hydrotalcite from south african coal fly ash. Powder Technol. 2017, 312, 299-309. [CrossRef]

42. Frias, M.; Rodriguez Largo, O.; Garcia Jimenez, R.; Vegas, I. Influence of activation temperature on reaction kinetics in recycled clay waste-calcium hydroxide systems. J. Am. Ceram. Soc. 2008, 91, 4044-4051. [CrossRef]

43. Ferreiro, S.; Blasco, T.; de Rojas, M.I.S.; Frias, M. Influence of activated art paper sludge-lime ratio on hydration kinetics and mechanical behavior in mixtures cured at 20 degrees c. J. Am. Ceram. Soc. 2009, 92, 3014-3021. [CrossRef]

44. Tichit, D.; Coq, B. Catalysis by hydrotalcites and related materials. Cattech 2003, 7, 206-217. [CrossRef]

45. Debecker, D.P.; Gaigneaux, E.M.; Busca, G. Exploring, tuning, and exploiting the basicity of hydrotalcites for applications in heterogeneous catalysis. Chem. Eur. J. 2009, 15, 3920-3935. [CrossRef]

46. Abello, S.; Medina, F.; Tichit, D.; Perez-Ramirez, J.; Groen, J.C.; Sueiras, J.E.; Salagre, P.; Cesteros, Y. Aldol condensations over reconstructed $\mathrm{mg}$-al hydrotalcites: Structure-activity relationships related to the rehydration method. Chem. Eur. J. 2005, 11, 728-739. [CrossRef]

47. Tichit, D.; Bennani, M.N.; Figueras, F.; Tessier, R.; Kervennal, J. Aldol condensation of acetone over layered double hydroxides of the meixnerite type. Appl. Clay Sci. 1998, 13, 401-415. [CrossRef]

48. Climent, M.J.; Corma, A.; Fornes, V.; Guil-Lopez, R.; Iborra, S. Aldol condensations on solid catalysts: A cooperative effect between weak acid and base sites. Adv. Synth. Catal. 2002, 344, 1090-1096. [CrossRef] 
49. Guida, A.; Lhouty, M.H.; Tichit, D.; Figueras, F.; Geneste, P. Hydrotalcites as base catalysts. Kinetics of claisen-schmidt condensation, intramolecular condensation of acetonylacetone and synthesis of chalcone. Appl. Catal. A Gen. 1997, 164, 251-264. [CrossRef]

50. Kikhtyanin, O.; Tisler, Z.; Velvarska, R.; Kubicka, D. Reconstructed mg-al hydrotalcites prepared by using different rehydration and drying time: Physico-chemical properties and catalytic performance in aldol condensation. Appl. Catal. A Gen. 2017, 536, 85-96. [CrossRef]

51. Tisler, Z.; Vrbkova, E.; Kocik, J.; Kadlec, D.; Vyskocilova, E.; Cerveny, L. Aldol condensation of benzaldehyde and heptanal over zinc modified mixed mg/al oxides. Catal. Lett. 2018, 148, 2042-2057. [CrossRef]

52. Choudary, B.M.; Kantam, M.L.; Reddy, C.R.V.; Rao, K.K.; Figueras, F. The first example of michael addition catalysed by modified mg-al hydrotalcite. J. Mol. Catal. A Chem. 1999, 146, 279-284. [CrossRef]

53. Kaneda, K.; Ueno, S.; Imanaka, T. Heterogeneous baeyer-villiger oxidation of ketones using an oxidant consisting of molecular-oxygen and aldehydes in the presence of hydrotalcite catalysts. J. Chem. Soc. Chem. Commun. 1994, 797-798. [CrossRef]

54. Pillai, U.R.; Sahle-Demessie, E. Sn-exchanged hydrotalcites as catalysts for clean and selective baeyer-villiger oxidation of ketones using hydrogen peroxide. J. Mol. Catal. A Chem. 2003, 191, 93-100. [CrossRef]

55. Climent, M.J.; Corma, A.; Iborra, S. Heterogeneous catalysts for the one-pot synthesis of chemicals and fine chemicals. Chem. Rev. 2011, 111, 1072-1133. [CrossRef]

56. Tichit, D.; Ortiz, M.D.M.; Francova, D.; Gerardin, C.; Coq, B.; Durand, R.; Prinetto, F.; Ghiotti, G. Design of nanostructured multifunctional pd-based catalysts from layered double hydroxides precursors. Appl. Catal. A Gen. 2007, 318, 170-177. [CrossRef]

57. Climent, M.J.; Corma, A.; Iborra, S.; Mifsud, M.; Velty, A. New one-pot multistep process with multifunctional catalysts: Decreasing the e factor in the synthesis of fine chemicals. Green Chem. 2010, 12, 99-107. [CrossRef]

58. Colmenares, M.C.; Mare, E. Removal of chloride ions from de wastewater using hydrotalcites as adsorbent materials. Ing. UC 2017, 24, 204-217.

59. Jawad, A.; Peng, L.; Liao, Z.W.; Zhou, Z.H.; Shahzad, A.; Ifthikar, J.; Zhao, M.M.; Chen, Z.L.; Chen, Z.Q. Selective removal of heavy metals by hydrotalcites as adsorbents in diverse wastewater: Different intercalated anions with different mechanisms. J. Clean Prod. 2019, 211, 1112-1126. [CrossRef]

60. Rosset, M.; Sfreddo, L.W.; Hidalgo, G.E.N.; Perez-Lopez, O.W.; Feris, L.A. Adsorbents derived from hydrotalcites for the removal of diclofenac in wastewater. Appl. Clay Sci. 2019, 175, 150-158. [CrossRef]

61. Tiwari, E.; Singh, N.; Khandelwal, N.; Monikh, F.A.; Darbha, G.K. Application of zn/al layered double hydroxides for the removal of nanoscale plastic debris from aqueous systems. J. Hazard. Mater. 2020, $397,9$. [CrossRef] [PubMed]

62. Linares, C.F.; Solano, S.; Infante, G. The influence of hydrotalcite and cancrinite-type zeolite in acidic aspirin solutions. Microporous Mesoporous Mater. 2004, 74, 105-110. [CrossRef]

63. Leon-Vallejo, A.M.; Fetter, G.; Sampieri, A.; Rubio-Rosas, E. Synthesis of cotton fibers impregnated with bactericidal hydrotalcites to be used in medical textile supplies. MRS Adv. 2017, 2, 3787-3795. [CrossRef]

64. Rives, V.; Perez-Bernal, M.E.; Ruano-Casero, R.J.; Nebot-Diaz, I. Development of a black ceramic pigment from non stoichiometric hydrotalcites. J. Eur. Ceram. Soc. 2012, 32, 975-987. [CrossRef]

65. Terry, P. Characterization of cr ion exchange with hydrotalcite. Chemosphere 2004, 57, 541-546. [CrossRef] [PubMed]

66. Kang, M.R.; Lim, H.M.; Lee, S.H.; Kim, K.J. Layered double hydroxide and its anion exchange capacity. Adv. Technol. Mater. Mater. Process. J. 2004, 6, 218-223.

67. Shin, H.-S.; Kim, M.-J.; Nam, S.-Y.; Moon, H.-C. Phosphorus removal by hydrotalcite-like compounds (htlcs). Water Sci. Technol. 1996, 34, 161-168.

68. Palin, L.; Milanesio, M.; van beek, W.; Conterosito, E. Understanding the ion exchange process in ldh nanomaterials by fast in situ xrpd and pca-assisted kinetic analysis. J. Nanomater. 2019, 2019, 1-9. [CrossRef]

69. Bontchev, R.P.; Liu, S.; Krumhansl, J.L.; Voigt, J.; Nenoff, T.M. Synthesis, characterization, and ion exchange properties of hydrotalcite mg6al2(oh)16(a)x(a')2-x·4h2o (a, $\mathrm{a}^{\prime}=\mathrm{cl}-, \mathrm{br}-, \mathrm{i}^{-}$, and no3-, $2 \geq \mathrm{x} \geq 0$ ) derivatives. Chem. Mater. 2003, 15, 3669-3675. [CrossRef]

70. Miyata, S. Anion-exchange properties of hydrotalcite-like compounds. Clays Clay Miner. 1983, 31, $305-311$. [CrossRef] 
71. Coenen, K.; Gallucci, F.; Cobden, P.; van Dijk, E.; Hensen, E.J.M.; Annaland, M.v.S. Chemisorption of h2o and $\mathrm{CO}_{2}$ on hydrotalcites for sorption-enhanced water-gas-shift processes. Energy Proc. 2017, 114, 2228-2242. [CrossRef]

72. Bhatta, L.K.G.; Subramanyam, S.; Chengala, M.D.; Bhatta, U.M.; Venkatesh, K. Enhancement in $\mathrm{CO}_{2}$ adsorption on hydrotalcite-based material by novel carbon support combined with $\mathrm{K}_{2} \mathrm{CO}_{3}$ impregnation. Ind. Eng. Chem. Res. 2015, 54, 10876-10884. [CrossRef]

73. Ding, Y.; Alpay, E. Equilibria and kinetics of $\mathrm{CO}_{2}$ adsorption on hydrotalcite adsorbent. Chem. Eng. Sci. 2000, 55, 3461-3474. [CrossRef]

74. Hufton, J.R.; Mayorga, S.; Sircar, S. Sorption-enhanced reaction process for hydrogen production. AIChE J. 1999, 45, 248-256. [CrossRef]

75. Yang, J.-I.; Kim, J.-N. Hydrotalcites for adsorption of $\mathrm{CO}_{2}$ at high temperature. Korean J. Chem. Eng. 2006, 23, 77-80. [CrossRef]

76. Yong, Z.; Mata; Rodrigues, A.E. Adsorption of carbon dioxide onto hydrotalcite-like compounds (htlcs) at high temperatures. Ind. Eng. Chem. Res. 2001, 40, 204-209. [CrossRef]

77. Moreira, R.F.P.M.; Soares, J.L.; Casarin, G.L.; Rodrigues, A.E. Adsorption of $\mathrm{CO}_{2}$ on hydrotalcite-like compounds in a fixed bed. Sep. Sci. Technol. 2006, 41, 341-357. [CrossRef]

78. Machner, A.; Zajac, M.; Ben Haha, M.; Kjellsen, K.O.; Geiker, M.R.; De Weerdt, K. Chloride-binding capacity of hydrotalcite in cement pastes containing dolomite and metakaolin. Cem. Concr. Res. 2018, 107, 163-181. [CrossRef]

79. Poonoosamy, J.; Brandt, F.; Stekiel, M.; Kegler, P.; Klinkenberg, M.; Winkler, B.; Vinograd, V.; Bosbach, D.; Deissmann, G. Zr-containing layered double hydroxides: Synthesis, characterization, and evaluation of thermodynamic properties. Appl. Clay Sci. 2018, 151, 54-65. [CrossRef]

80. Król, B.; Pielichowska, K.; Król, P.; Kędzierski, M. Polyurethane cationomer films as ecological membranes for building industry. Prog. Org. Coatings 2019, 130, 83-92. [CrossRef]

81. Nishimura, S.; Takagaki, A.; Ebitani, K. Characterization, synthesis and catalysis of hydrotalcite-related materials for highly efficient materials transformations. Green Chem. 2013, 15, 2026-2042. [CrossRef]

82. Olguin, M.T.; Bosch, P.; Acosta, D.; Bulbulian, S. I-131(-) sorption by thermally treated hydrotalcites. Clay Clay Min. 1998, 46, 567-573. [CrossRef]

83. Balsley, S.D.; Brady, P.V.; Krumhansl, J.L.; Anderson, H.L. Anion scavengers for low-level radioactive waste repository backfills. J. Soil Contam. 1998, 7, 125-141. [CrossRef]

84. James, A.; Bazarchi, E.; Chiniforush, A.A.; Aghdam, P.P.; Hosseini, M.R.; Akbarnezhad, A.; Martek, I.; Ghodoosi, F. Rebar corrosion detection, protection, and rehabilitation of reinforced concrete structures in coastal environments: A review. Constr. Build. Mater. 2019, 224, 1026-1039. [CrossRef]

85. Song, H.W.; Saraswathy, V. Corrosion monitoring of reinforced concrete structures-a review. Int. J. Electrochem. Sci. 2007, 2, 1-28.

86. Verma, S.K.; Bhadauria, S.S.; Akhtar, S. Monitoring corrosion of steel bars in reinforced concrete structures. Sci. World J. 2014. [CrossRef]

87. Shi, X.; Fay, L.; Yang, Z.; Nguyen, T.A.; Liu, Y. Corrosion of deicers to metals in transportation infrastructure: Introduction and recentdevelopments. Corros. Rev. 2009, 27, 23. [CrossRef]

88. Rodrigues, M.P.M.C.; Costa, M.R.N.; Mendes, A.M.; Eusébio Marques, M.I. Effectiveness of surface coatings to protect reinforced concrete in marine environments. Mater. Struct. 2000, 33, 618-626. [CrossRef]

89. Raupach, M.; Wolff, L. Long-term durability of hydrophobic treatment on concrete. Surf. Coatings Int. Part B Coatings Trans. 2005, 88, 127-133. [CrossRef]

90. Medeiros, M.; Helene, P. Efficacy of surface hydrophobic agents in reducing water and chloride ion penetration in concrete. Mater. Struct. 2008, 41,59-71. [CrossRef]

91. Chung, D.D.L. Use of polymers for cement-based structural materials. J. Mater. Sci. 2004, 39, $2973-2978$. [CrossRef]

92. Montemor, M.F.; Simões, A.M.P.; Salta, M.M. Effect of fly ash on concrete reinforcement corrosion studied by eis. Cem. Concr. Compos. 2000, 22, 175-185. [CrossRef]

93. Arya, C.; Xu, Y. Effect of cement type on chloride binding and corrosion of steel in concrete. Cem. Concr. Res. 1995, 25, 893-902. [CrossRef]

94. Yang, Z.; Fischer, H.; Polder, R. Modified hydrotalcites as a new emerging class of smart additive of reinforced concrete for anticorrosion applications: A literature review. Mater. Corros. 2013, 64, 1066-1074. [CrossRef] 
95. Yang, Z.; Fischer, H.; Cerezo, J.; Mol, J.M.C.; Polder, R. Modified hydrotalcites for improved corrosion protection of reinforcing steel in concrete-Preparation, characterization, and assessment in alkaline chloride solution. Mater. Corros. 2016, 67, 721-738. [CrossRef]

96. Yang, Z.X.; Fischer, H.; Cerezo, J.; Mol, J.M.C.; Polder, R. Aminobenzoate modified mg-al hydrotalcites as a novel smart additive of reinforced concrete for anticorrosion applications. Constr. Build. Mater. 2013, 47, 1436-1443. [CrossRef]

97. Yang, Z.; Fischer, H.; Polder, R. The Application of Modified Hydrotalcites as Chloride Scavengers and Inhibitor Release Agents in Cem. Mortars; Crc Press-Taylor \& Francis Group: Boca Raton, FL, USA, 2014; pp. 461-469.

98. Pan, C.; Chen, N.; He, J.; Liu, S.; Chen, K.; Wang, P.; Xu, P. Effects of corrosion inhibitor and functional components on the electrochemical and mechanical properties of concrete subject to chloride environment. Constr. Build. Mater. 2020, 260, 119724. [CrossRef]

99. Yang, Z.X.; Polder, R.; Mol, J.M.C.; Andrade, C. The effect of two types of modified mg-al hydrotalcites on reinforcement corrosion in cement mortar. Cem. Concr. Res. 2017, 100, 186-202. [CrossRef]

100. Cao, Y.H.; Zheng, D.J.; Dong, S.G.; Zhang, F.; Lin, J.Y.; Wang, C.; Lin, C.J. A composite corrosion inhibitor of mgal layered double hydroxides co-intercalated with hydroxide and organic anions for carbon steel in simulated carbonated concrete pore solutions. J. Electrochem. Soc. 2019, 166, C3106-C3113. [CrossRef]

101. Lozano-Lunar, A.; Ledesma, E.F.; Esquinas, A.R.; Romero, J.R.J.; Rodriguez, J.M.F. A double barrier technique with hydrotalcites for $\mathrm{pb}$ immobilisation from electric arc furnace dust. Materials 2019, 12, 16. [CrossRef]

102. Machner, A.; Zajac, M.; Ben Haha, M.; Kjellsen, K.O.; Geiker, M.R.; De Weerdt, K. Limitations of the hydrotalcite formation in portland composite cement pastes containing dolomite and metakaolin. Cem. Concr. Res. 2018, 105, 1-17. [CrossRef]

103. Szybilski, M.; Nocun-Wczelik, W. The effect of dolomite additive on cement hydration. Proc. Eng. 2015, 108, 193-198. [CrossRef]

104. Land, G.; Stephan, D. Controlling cement hydration with nanoparticles. Cem. Concr. Compos. 2015, 57, 64-67. [CrossRef]

105. Bräu, M.; Ma-Hock, L.; Hesse, C.; Nicoleau, L.; Strauss, V.; Treumann, S.; Wiench, K.; Landsiedel, R.; Wohlleben, W. Nanostructured calcium silicate hydrate seeds accelerate concrete hardening: A combined assessment of benefits and risks. Arch. Toxicol. 2012, 86, 1077-1087. [CrossRef]

106. Xu, J.; Lu, D.; Zhang, S.; Ling, K.; Xu, Z. Pore structures of mortars with dolomite and limestone powders cured at various temperatures. J. Chin. Ceram. Soc. 2017, 45, 268-273.

107. Li, H.; Guan, X.; Yang, L.; Liu, S.; Zhang, J.; Guo, Y. Effects of lial-layered double hydroxides on early hydration of calcium sulphoaluminate cement paste. J. Wuhan Univ. Technol. Mater. Sci. Ed. 2017, 32, 1101-1107. [CrossRef]

108. Chen, Y.; Yu, R.; Wang, X.; Chen, J.; Shui, Z. Evaluation and optimization of ultra-high performance concrete (uhpc) subjected to harsh ocean environment: Towards an application of layered double hydroxides (ldhs). Constr. Build. Mater. 2018, 177, 51-62. [CrossRef]

109. Zou, D.; Wang, K.; Li, H.; Guan, X. Effect of lial-layered double hydroxides on hydration of calcium sulfoaluminate cement at low temperature. Constr. Build. Mater. 2019, 223, 910-917. [CrossRef]

110. Yang, Z.; Fischer, H.; Polder, R. Laboratory investigation of the influence of two types of modified hydrotalcites on chloride ingress into cement mortar. Cem. Concr. Compos. 2015, 58, 105-113. [CrossRef]

111. Mir, Z.M.; Bastos, A.; Höche, D.; Zheludkevich, M.L. Recent advances on the application of layered double hydroxides in concrete-a review. Materials 2020, 13, 1426. [CrossRef]

112. Qu, Z.Y.; Yu, Q.L.; Brouwers, H.J.H. Relationship between the particle size and dosage of ldhs and concrete resistance against chloride ingress. Cem. Concr. Res. 2018, 105, 81-90. [CrossRef]

113. Ke, X.; Bernal, S.A.; Provis, J.L. Controlling the reaction kinetics of sodium carbonate-activated slag cements using calcined layered double hydroxides. Cem. Concr. Res. 2016, 81, 24-37. [CrossRef]

114. Khan, M.S.H.; Kayali, O.; Troitzsch, U. Chloride binding capacity of hydrotalcite and the competition with carbonates in ground granulated blast furnace slag concrete. Mater. Struct. 2016, 49, 4609-4619. [CrossRef]

115. Raki, L.; Beaudoin, J.J.; Mitchell, L. Layered double hydroxide-like materials: Nanocomposites for use in concrete. Cem. Concr. Res. 2004, 34, 1717-1724. [CrossRef]

116. Kim, M.S.; Jun, Y.; Lee, C.; Oh, J.E. Use of cao as an activator for producing a price-competitive non-cement structural binder using ground granulated blast furnace slag. Cem. Concr. Res. 2013, 54, 208-214. [CrossRef] 
117. Peng, H.-K.; Wang, X.X.; Li, T.-T.; Huang, S.-Y.; Lin, Q.; Shiu, B.-C.; Lou, C.-W.; Lin, J.-H. Effects of hydrotalcite on rigid polyurethane foam composites containing a fire retarding agent: Compressive stress, combustion resistance, sound absorption, and electromagnetic shielding effectiveness. RSC Adv. 2018, 8, 33542-33550. [CrossRef]

118. Gómez-Fernández, S.; Ugarte, L.; Peña-Rodriguez, C.; Zubitur, M.; Corcuera, M.Á.; Eceiza, A. Flexible polyurethane foam nanocomposites with modified layered double hydroxides. Appl. Clay Sci. 2016, 123, 109-120. [CrossRef]

119. Gómez-Fernández, S.; Ugarte, L.; Peña-Rodriguez, C.; Corcuera, M.Á.; Eceiza, A. The effect of phosphorus containing polyol and layered double hydroxides on the properties of a castor oil based flexible polyurethane foam. Polym. Degrad. Stab. 2016, 132, 41-51. [CrossRef]

120. Sun, G.; Liu, L.; Wang, J.; Wang, H.; Wang, W.; Han, S. Effects of hydrotalcites and tris (1-chloro-2-propyl) phosphate on thermal stability, cellular structure and fire resistance of isocyanate-based polyimide foams. Polym. Degrad. Stab. 2015, 115, 1-15. [CrossRef]

121. Evans, D.G.; Duan, X. Preparation of layered double hydroxides and their applications as additives in polymers, as precursors to magnetic materials and in biology and medicine. Chem. Commun. 2006, 485-496. [CrossRef]

Publisher's Note: MDPI stays neutral with regard to jurisdictional claims in published maps and institutional affiliations.

(C) 2020 by the authors. Licensee MDPI, Basel, Switzerland. This article is an open access article distributed under the terms and conditions of the Creative Commons Attribution (CC BY) license (http://creativecommons.org/licenses/by/4.0/). 